University of Nebraska - Lincoln

DigitalCommons@University of Nebraska - Lincoln

Faculty Publications -- Department of English

English, Department of

2-1904

Notes on Tennyson's Lancelot and Elaine

Louise Pound

Follow this and additional works at: https://digitalcommons.unl.edu/englishfacpubs

Part of the Comparative Literature Commons, English Language and Literature Commons, Modern Literature Commons, and the Reading and Language Commons

This Article is brought to you for free and open access by the English, Department of at DigitalCommons@University of Nebraska - Lincoln. It has been accepted for inclusion in Faculty Publications -Department of English by an authorized administrator of DigitalCommons@University of Nebraska - Lincoln. 


\section{NOTES ON TENNYSON'S Lancelot and Elaine.}

\section{Thannrson amd Eluis' Specimens.}

The chief sources of Tennyson's Idylls are, as so well known, Malory's Morte Darthur and the Mabinogion. Secondary sources are the chronicles of Geoffrey of Monmouth, from whom the poet derived a few name-forms like Igerne and Gorlois, and stray touches in the handling, and the anonymous history, ascribed to Nennius, from which (Lancelot and Elaine, 1l. 284-315) he derived his account of Arthur's twelve battles. In 1889, Dr. Walther Wüllenweber ${ }^{1}$ pointed out that Tennyson seems also to have drawn upon Ellis' Specimens of Early English Metrical Romances, ${ }^{2}$ for a few proper names, like Bellicent and Anguisant, not found elsewhere.

It seems probable that Tennyson owes certain other suggestions to Ellis. The following are possible cases, not hitherto noted, for the Idyll of Lancelot and Elaine :

(1). "Past to her chamber", etc. 11. $605 \mathrm{ff}$. Perhaps suggested by " retired to her chamber", etc. Ellis, p. 159. There is nothing to correspond to this passage concerning the Queen in the Morte Darthur.

(2). The suggestion of Elaine's kinsfolk at Camelot, 1l. 798, 840. In the Morte Darthur, Lancelot and Lavaine lodge at Winchester with a "ryche burgeis" (xvIII, $\mathbf{x}$ ); in Ellis, p. 156, with the Lord of Astolat's sister.

(3). The interview between Lancelot and the Queen, 11. $1170 \mathrm{ff}$. There is no interview at this point in the Morte Darthur. The trend of the Queen's speech in the Idyll may well have been prompted by her words in Ellis. Cf. p. 159.

(4). The story of Lancelot's childhood, ll. 1393 ff. Cf. Ellis, p. 143-144. This story is not given by Malory, or in other sources Tennyson usually drew upon.

\section{Shalott and Astolat.}

The name Shalott of Tennyson's early lyric on the theme of Lancelot and Elaine, The Lady of

\footnotetext{
'Herrig's Archiv, Ixxxirr.

'Bohn's Antiquarian Library, 1805, 2nd ed. revised by J. O. Hallowell, 1848.
}

Shalott, seems to be the poet's Anglicizing of the Italian Scalot, or perhaps Scalotta. The name of the castle of Elaine's father is spelled variously, Ascolat (Malory), Ascolat or Ascalot (Morte Arthure, 'Thornton Ms.), Escalot (French prose Lancelot), etc. The source of The Lady of Shalott, according to Hallam Tennyson, who agrees with F. T. Palgrave," is " an Italian novelette 'Donna di Scalotta'". In Modern Language Notes, xvIr, 8, Mr. L. S. Potwin remarks, in a discussion of the source of Tennyson's lyric, that Professor Palgrave had probably never seen the Italian romance, else he would have referred to it more definitely. Mr. Potwin also quotes the suggestion by Mr. Churton Collins, ${ }^{5}$ that Novella LXxxI (Qui conta come la damigella di Scalot morì per amore di Lancialotto de Lac) of a collection published at Milan in 1804, is possibly the Italian source in question. The exact title given by $\mathbf{M r}$. Potwin, from the copy of the collection in the Harvard library, is Raccolta di Novelle, Vol. I. Milan, 1804.

In 1900 , I noticed in the library of Columbia University, the Novella, Qui conta, etc. in Cento Novelle Antichi (no. lxxxi), Milan, 1825. I cannot say what is the relation between the Raccolta and the Cento Novelle, which is published, I think, in one small volume; but I remember my impression, at the time, that Tennyson may well have known this collection, or edition, of 1825 , when he wrote The Lady of Shalott, published in 1832. Since the Novella seems the same in the two collections, it is, in any case, probably a matter of minor importance whether Tennyson, if the romance be the real source of his lyric, knew the Raccolta di Novelle of 1804 (he was born in 1809), or the Cento Novelle Antichi of 1825. The words of Palgrave and of Hallam Tennyson hardly sound as though it were Roscoe's translation ${ }^{6}$ (1825) which Tennyson knew.

\section{The Name Guinevere.}

Tennyson's spelling, Guinevere, seems to be an arbitrary modification of Malory's Guenever. The

${ }^{3}$ Lyrical Poems by Alfred Lord Tennyson, 1885.

- Memoir, I, 91.

${ }^{5}$ Early Poems by Alfred Lord Tennyson, 1900.

'Poems by Tennyson. Van Dyke and Chambers, 1903, p. 363. 
poet's usual sources for his proper names in the Idylls are, as indicated above, Malory, Ellis, Geoffrey of Monmouth, and the Mabinogion; and this case is one of his few departures. Forms of the name are almost countless. To cite some of them, Crestien de Troyes has Genièvre, so Wace. Pierre of Langtoft has Gainovere, Alain Bouchard, Guennaran. German forms are Ginover, and Ginevra (so the Italian of Ariosto and Petrarch). English forms are Wenhauer (Layamon), Guerwar (Robert of Gloucester), Guenor (Gawayn and the Grene Knight), Gaynour, Wanour (Morte Arthure, Thornton Ms.). Hughes has Guenevera (Misfortunes of Arthur), Heber Ganora (Morte Arthur, 1841), Simcox Ganore (Poems and Romances, 1869), etc. One case with initial Gui- noted is Guinever, which occurs in a note in Ritson's Ancient Engleish Metrical Romances, II, p. 40.

Possibly Tennyson derived his spelling from some definite source; but it seems much more probable that he made over Malory's name to please his poetic fancy, much as he coined the name of the Queen's father, Leodogran (The Coming of Arthur) from the Leodograunce of Malory and the Leodegan of Ellis.

Tennyson's Guinevere is now much the most familiar version of the name, and is often found even where it should not be. The poem by William Morris, The Defence of Guenevere, 1858, suffers especially from Tennysonian influence. A few of many instances noted of inaccurate quotation are: Ryland, Chronological Outlines of English Literature, 1890, pp. 212, 311; “William Morris' Defence of Guinevere", R. P. Halleck, History of English Literature, 1900, p. 92 (uncorrected in revised editions); "The Defencc of Guinevere, Morris' earliest volume," V. D. Scudder, Introduction to the History of English Literature, p. 511. 